\title{
SURVEI MINAT MASYARAKAT TERHADAP PERKEMBANGAN PENCAK SILAT DI KABUPATEN KARAWANG
}

\author{
Ahmad Balya Baehaki ${ }^{1}$, Rizki Aminudin ${ }^{2}$, Rahmat Iqbal ${ }^{3}$ \\ Program Studi Pendidikan Jasmani Kesehatan Dan Rekreasi, \\ FKIP - Universitas Singaperbangsa Karawang ${ }^{1}$ \\ ahmadbalyabaehaki1501@gmail.com
}

\begin{abstract}
ABSTRAK
Penelitian ini bertujuan untuk mengetahui seberapa besar minat masyarakat terhadap pencak silat di kabupaten Karawang. Permasalahan dari penelitian ini adalah untuk mengetahui bagaimana masyarakat mengembangkan pencak silat di kabupaten Karawang. Penelitian ini merupakan penelitian deskriptif kualitatif, yang menggambarkan bagaimana minat masyarakat terhadap pencak silat di kabupaten Karawang, subjek dalam penelitian ini adalah 27 perguruan pencak silat yang ada di kabupaten Karawang. Teknik pengumpulan data yang digunakan dalam penelitian ini adalah observasi, wawancara, dan dokumentasi. Teknik analisis data yang digunakan dalam penelitian ini adalah teknik reduksi data, penyajian data dan penarikan kesimpulan. Hasil penelitian menunjukan bahwa minat masyarakat terhadap perkembangan pencak silat sudah cukup banyak, juga dalam pengorganisasian nya sudah baik, selain itu sarana dan prasarana di masing - masing perguruan pencak silat yang kurang lengkap untuk memenuhi proses latihan, oleh karena itu diperlukan edukasi untuk perkembangan pencak silat khususnya di kabupaten Karawang.
\end{abstract}

Kata Kunci: Pencak silat, Perkembangan, Karawang.

\section{ABSTRACT}

This study aims to determine how much public interest in pencak silat in Karawang district. The problem of this research is to find out how people develop pencak silat in Karawang district. This research is a qualitative descriptive study, which describes how the public's interest in pencak silat in Karawang district. The subjects in this study are 27 pencak silat colleges in Karawang district. Data collection techniques used in this study were observation, interviews, and documentation. The data analysis techniques used in this study were data reduction techniques, data presentation and conclusion drawing. The results showed that the public's interest in the development of pencak silat was quite a lot, also in the organization it was good, besides that the facilities and infrastructure in each pencak silat school were incomplete to fulfill the training process, therefore education was needed for the development of pencak silat. especially in Karawang district.

Key Words: Martial art, development, Karawang.

Dipublikasikan Oleh :

UPT Publikasi dan Pengelolaan Jurnal

Universitas Islam Kalimantan Muhammad Arsyad Al-Banjari Banjarmasin 


\section{PENDAHULUAN}

Minat masyarakat terhadap beladiri pencak silat sekarang ini sudah tidak bisa diragukan lagi, hal ini terlihat dari banyak peminat olahraga ini mulai dari masyarakat-masyarakat sampai orang tua. Berdasarkan informasi yang diperoleh, olahraga pencak silat merupakan olahraga yang cukup diminati bagi masyarakat. Minat tanpa ada paksaan dari siapapun, minat itu dari dalam diri individu, ada pun dari dorongan teman-teman atau dari lingkungan tersebut. Misalnya ditempat kita tinggal atau sekitarnya.

Nilai kepuasan berkurang, minat pun menjadi berkurang. Setiap minat memuaskan suatu kebutuhan dalam kehidupan masyarakat walaupun kebutuhan ini mungkin tidak segera tampak bagi orang dewasa. Semakin kuat kebutuhan ini, semakin kuat dan bertahan minat tersebut. Selanjutnya makin sering minat diekspresikan dalam kegiatan semakin kuatlah minat tersebut. Sebaliknya minat akan padam bila tidak disalurkan. Misalnya lingkungan tempat masyarakat hidup membatasi kesempatan masyarakat dalam bermain mulai berkurang dan minat lain akan menggantikannya.

Pencak silat adalah kata mejemuk. Pencak dan Silat mempunyai pengertian yang sama dan merupakan bagian dari kebudayaan masyarakat pribumi Asia Tenggara, yakni kelompok masyarakat etnis hyangmerupakan penduduk asli Negara-negara di kawasan Asia Tenggara. Kata Pencak biasa digunakan oleh masyarakat pulau Jawa, Madura, dan Bali, sedangkan Silat biasa digunakan oleh masyarakat di wilayah Indonesia lainnya maupun di Malaysia, Singapura, Brunei Darussalam serta di Thailand (bagian Selatan), bdan Filipina. Penggabungan kata pencak dan silat menjadi kata majemuk untuk pertama kalinya dilakukan pada waktu dibentuk suatu organisasi persatuan dan perguruan Pencak dan perguruan Silatdi Indonesia yang diberi nama Ikatan Pencak Silat Indonesia, disingkat IPSI pada tahun 1948 di Surakarta.

Pencak silat merupakan salah satu budaya asli bangsa Indonesia, yang sudah diterima oleh masyarakat internasional, dimana perkembangan sebagai olahraga moderen yang diterima oleh masyarakat luas akan memberikan konsekuensi 'logis' bahwa pencak silat akan di pelajari dan di tekuni oleh masyarakat atau peserta didik yang mempelajarinya.

Memberikan sumbangan pemikiran dan informasi bagi perkembangan pencak silat di Kabupaten Karawang. Dalam penelitian ini terdapat dua variabel yaitu variabel bebas dan terikat. Variabel bebasnya yaitu minat masyarakat dan variabel terikatnya adalah perkembangan pencak silat. Sasaran yang dituju peneliti adalah perguruan - perguruan pencak silat yang ada di Kabupaten Karawang.

Berdasarkan uraian tersebut setelah diamati dilingkungan masyarakat maka peneliti tertarik untuk melakukan penelitian yang membahas tentang perkembangan pencak silat khususnya yang ada di wilayah Kabupaten Karawang dengan judul "Survei Minat Masyarat Terhadap Perkembangan Pencak Silat di Kabupaten Karawang". Dalam penelitian ini peneliti menggunakan pendekatan kualitatif. Penelitian ini bertujuan untuk memperoleh informasi tentang perguruan - perguruan pencak silat yang ada di Kabupaten Karawang yang selanjutnya akan di telaah, dipelajari dan di amati perkembangan perguruan - perguruan pencak silat yang ada di Kabupaten Karawang.

\section{METODE}

Dalam penelitian ini peneliti menggunakan pendekatan kualitatif. Penelitian ini bertujuan untuk memperoleh informasi tentang perguruan - perguruan pencak silat yang ada di Kabupaten Karawang yang selanjutnya akan di telaah, dipelajari dan di amati perkembangan perguruan - perguruan pencak silat yang ada di Kabupaten Karawang.

Dalam penelitian ini metode yang gunakan peneliti adalah metode Deskriptif Analisis dengan pendekatan kualitatif. Penelitian ini bertujuan untuk memperoleh informasi tentang perguruan - perguruan pencak silat yang ada di Kabupaten Karawang yang selanjutnya akan di telaah, dipelajari dan di amati perkembangan perguruan perguruan pencak silat yang ada di Kabupaten Karawang.

Dalam sebuah penilitian yang harus diperhatikan yaitu berfikir rasional seperti kegiatan yang dilakukan dengan cara yang masuk akal, sehingga terjangkau oleh penalaran manusia. Empiris berarti cara yang dilakukan itu dapat diamati oleh indra penglihatan manusia, sehingga orang lain dapat mengamati dan mengetahui cara yang digunakan. Selanjutnya sistematis yang menggunakan langkah - langkah tertentu yang bersifat logis. Metode penelitian ini juga menggunakan deskriptif analisis untuk memudahkan peneliti dalam melakukan penelitian. Metode deskriptif analisis digunakan untuk mempermudah peneliti dalam menyusun, menjelaskan, dan menganalisis tentang perguruan - perguruan pencak silat yang ada di Kabupaten Karawang. 
Dari pemaparan diatas dapat disimpulkan bahwa, metode deskriptif dapat memaparkan kesenjangan kesenjangan yang terjadi dimasyarakat dan berlangsung pada masa sekarang. Selain itu untuk mencapai tujuan penelitian berupa deskriptif atau gambaran yang diteliti yaitu tentang perguruan - perguruan pencak silat yang ada di Kabupaten Karawang, juga merumuskan masalah, mengumpulkan data, menalisis data untuk menjawab masalah, merumuskan kesimpulan serta menyusun penelitian.

Populasi adalah wilayah generalisasi yang terdiri atas : objek/subjek yang mempunyai kualitas dan karakteristik tertentu yang di tetapkan oleh peneliti untuk di pelajari dan kemudian ditarik kesimpulannya (Sugiyono, 2014 : 80). Maksud dari pernyataan tersebut adalah banyaknya subjek keseluruhan dari sampel yang akan diambil. Oleh karena itu, yang menjadi populasi dalam penelitian ini adalah perguruan - perguruan pencak silat yang ada di Kabupaten Karawang yang sebanyak 54 perguruan pencak silat.

Sample adalah bagian dari jumlah dan karakteristik yang dimiliki oleh populasi tersebut. Bila populasi besar, dan peneliti tidak mungkin mempelajari semua yang ada pada populasi, misalnya karena keterbatasan dana, tenaga, dan waktu, maka peneliti dapat menggunakan sampel yang diambil dari populasi itu, keimpulannya akan dapat di berlakukan untuk populasi. Untuk sampel yang diambil dari populasi harus betul betul reprsentatif (mewakili) (Sugiyono, $2014: 81$ ).

Teknik sampel Probability Sampling menurut Sugiyono (2014 : 82) teknik pengambilan sampel yang memberikan peluang yang sama bagi setiap unsur (anggota) populasi untuk dipilih menjadi anggota sampel. Teknik ini meliputi, simple random sampling, proportionate straitified random sampling, disproportionate straitified random sampling, sampling area (cluster) sampling (sampel menurut daerah).

Data yang diambil yaitu cluster sampling (area sampling) Misalnya di Kabupaten Karawang terdapat 54 perguruan pencak silat, dan sampel nya menggunakan 27 perguruan pencak silat, maka pengambilan 27 perguruan pencak silat itu dilakukan secara random. Tetapi perlu di ingat karena perguruan - perguruan pencak silat di Indonesia tidak berstrata (tidak sama) maka pengambilan sampelnya perlu menggunakan stratified random sampling. Teknik sampling daerah ini sering digunakan melalui dua tahap, yaitu tahap pertama menentukan sampel daerah, dan tahap berikutnya menentukan orang-orang yang ada pada daerah itu secara sampling juga.

Pendekatan kualitatif, yang menjadi instrumen penelitian adalah si peneliti itu sendiri. Peneliti kualitatif sebagai human instrumen, berfungsi menetapkan fokus penelitian, memilih narasumber sebagai sumber data, melakukan pengumpulan data, menilai kualitas data, analisis data, menafsirkan data dan membuat kesimpulan atas semuanya. Di samping peneliti sebagai instrumen utama, ada pula instrumen untuk melengkapi data-data dan membandingkan dengan data yang telah didapatkan melalui observasi dan wawancara (Sugiyono, 2014:305307). Jadi dalam penelitian ini, peneliti menjadi instrument penelitian itu sendiri, selain itu instrument yang digunakan adalah data-data yang diperoleh dari hasil wawancara, observasi, dan dokumentasi.

Tabel 1. Panduan Wawancara Terhadap Pihak Perguruan Pencak Silat

\begin{tabular}{cc}
\hline Ketua Perguruan Pencak Silat & Pelatih Pencak Silat \\
\hline Administrasi & Administrasi \\
AD/ART & Filosofi Logo \\
Sejarah Singkat & Lokasi \\
Filosofi Logo & Jumlah Anggota \\
Lokasi & Kepelatihan \\
Jumlah Anggota & \\
\hline Kegiatan & Kegiatan \\
Event & Event \\
Prestasi & Prestasi \\
Jadwal latihan & Jadwal latihan \\
Tempat latihan & Tempat latihan \\
\hline
\end{tabular}

\section{HASIL DAN PEMBAHASAN}

Penelitian ini merupakan penelitian deskriptif, sehingga keadaan objek akan digambarkan sesuai dengan keadaan sesungguhnya yang diperoleh oleh peneliti. Sebelum penelitian ini dilakukan peneliti telah meminta izin untuk melakukan penelitian pada pihak pencab IPSI Kabupaten Karawang tersebut. Dan mendapatkan izin pada tanggal 1 September 2020 untuk melakukan penelitian kelapangan langsung, pengambilan data ini dilakukan malalui tatap muka langsung. Responden sebanyak 27 perguruan pencak silat dari total populasi 54 perguruan pencak silat

Dipublikasikan Oleh : 
Data yang telah dikumpulkan melaui wawancara, serta catatan dari narasumber, selanjutnya direduksi dan dianalisis dengan menggunakan teknik deskriptif kualitatif. Melalui teknik ini berarti peneliti akan menggambarkan, menguraikan, dan menginterpretasikan data yang telah terkumpul sehingga akan memperoleh gambaran secara umum dan menyeluruh mengenai minat masyarakat terhadap perkembangan pencak silat di Kabupaten Karawang. Berikut hasil observasi kepada perguruan - perguruan pencak silat:

Tabel 2. Hasil Observasi Perguruan - Perguruan Pencak Silat Kab. Karawang

\begin{tabular}{|c|c|c|}
\hline Nama Perguruan Pencak Silat & Ketua Perguruan & Jumlah Anggota \\
\hline Perguruan Pencak Silat (PPS) Asma'ul Husna & Wayim, S.Pd, M.M & 150 \\
\hline Keluarga Pencak Silat (KPS) Al-Ikhlas '09 & Riki Lesmana, S.Pd & 200 \\
\hline Perguruan Pencak Silat (PPS) Bajing Kiring & Rd. Encep Permana & 1500 \\
\hline Perguruan Pencak Silat (PPS) Kencana Wulung & Siti Aminah & 200 \\
\hline Perguruan Pencak Silat (PPS) Gaya Murni & Mulyana Sadeli & 1100 \\
\hline Perguruan Pencak Silat (PPS) Dampal Bumi & Saepul Anwar, S.Pd & 300 \\
\hline Kesatuan Pencak Silat Masyarakat (Kilat Mas) & Rizki Aminudin, S.Pd, M.Pd & 200 \\
\hline Keluarga Pencak Silat Nusantara (KPSN) & Ardawi Sumarno, S.Pd, M.Pd & 1450 \\
\hline Perguruan Pencak Silat (PPS) Maung Taliwargi & Darwin & 250 \\
\hline Persilatan Macan Merah (PMM) & Ahmad Rifki Aziz & 170 \\
\hline Perguruan Pencak Silat (PPS) Macan Kumbang & Endang Suhendar & 300 \\
\hline Perguruan Pencak Silat (PPS) Panca Rasa & Abu, Amd & 120 \\
\hline Perguruan Pencak Silat (PPS) Raksa Budhi & Didin Baharudin, S.Pd & 1000 \\
\hline Perguruan Pencak Silat (PPS) Pusaka Kencana & Popon Urmayanti & 1275 \\
\hline Perguruan Pencak Silat (PPS) Persinas Asad & Gun Gun Yasaguna & 1000 \\
\hline Perguruan Pencak Silat (PPS) Satria Muda Indonesia & Cahyadi & 595 \\
\hline Perguruan Pencak Silat (PPS) Tribuana Mandala & Agus Sumitra & 200 \\
\hline Perguruan Pencak Silat (PPS) Taliwargi Siliwangi & Tris Nurrohman & 350 \\
\hline Perguruan Pencak Silat (PPS) Tadjimalela & Edi & 1000 \\
\hline Perguruan Pencak Silat (PPS) Suryapati & Rayyan Nuryadin & 50 \\
\hline Perguruan Pencak Silat (PPS) Suliwa & Jeje Jaenudin & 100 \\
\hline Perguruan Pencak Silat (PPS) Wahyu Alam & Kosasih & 225 \\
\hline Perguruan Pencak Silat (PPS) Tapak Suci & Guntur Syahputra & 250 \\
\hline Persaudaraan Setia Hati Terate (PSHT) & Supriyantoko & 500 \\
\hline Perguruan Pencak Silat (PPS) Perisai Diri & Baban Barlian, S.Pd & 220 \\
\hline Perguruan Pencak Silat (PPS) Merpati Putih & Yayan Hendriawan & 200 \\
\hline Perguruan Pencak Silat (PPS) Kera Sakti & M. Syukron & 150 \\
\hline \multicolumn{2}{|c|}{ Jumlah Masyarakat Yang Mengikuti Pencak Silat } & 13.055 \\
\hline
\end{tabular}

\section{PEMBAHASAN HASIL PENELITIAN}

1. Logo Perguruan Pencak Silat

Hasil wawancara dengan pihak perguruan pencak silat dan anggota perguruan pencak silat tersebut, mereka menyatakan bahwa logo perguruan pencak silat mereka memiliki makna tersendiri sesuai dengan bentuk dan gambarnya.

2. Sejarah Perguruan Pencak Silat

Hasil wawancara dengan pihak perguruan pencak silat dan anggota perguruan pencak silat tersebut, bahwa Sejarah perguruan pencak silat mereka beragam seperti berdiri sejak zaman penjajahan, era reformasi dan bahkan ada pula yang baru saja berdiri serta baru saja merintis perguruan pencak silat mereka dari awal.

3. Kepengurusan Perguruan Pencak Silat

Hasil wawancara kepada pihak perguruan pencak silat dan anggota perguruan pencak silat tersebut, kepengurusan perguruan pencak silat lebih banyak melibatkan masyarakat yang usianya muda serta memberikan kesempatan kepada yang lebih muda untuk belajar menjadi pengurus perguruan pencak silat di kabupaten karawang.

4. Jumlah Anggota Perguruan Pencak Silat

Hasil wawancara dengan pihak perguruan pencak silat dan anggota perguruan pencak silat tersebut, jumlah keanggotaan perguruan pencak silat di kabupaten karawang bervariasi, mulai dari puluhan, ratusan hingga ribuan dalam keanggotaan perguruan pencak silat yang ada di kabupaten karawang.

Dipublikasikan Oleh :

UPT Publikasi dan Pengelolaan Jurnal

Universitas Islam Kalimantan Muhammad Arsyad Al-Banjari Banjarmasin 
5. Lokasi Perguruan Pencak Silat

Hasil wawancara dengan pihak perguruan pencak silat dan anggota perguruan pencak silat tersebut, sebagian besar perguruan pencak silat yang ada di kabupaten karawang berasal dari kabupaten karawang, namun adapula yang berasal dari luar kabupaten karawang yang memiliki cabang perguruan pencak silat di kabupaten karawang seperti Perguruan Pencak Silat (PPS) Tapak Suci, Perguruan Pencak Silat (PPS) Merpati Putih, Perguruan Pencak Silat (PPS) Nasional Persinas Asad, Persaudaraan Setia Hati Terate, Keluarga Pencak Silat Nusantara (KPSN), Perguruan Pencak Silat (PPS) Maung Tali Wargi, Perguruan Pencak Silat (PPS) Raksa Budhi, Perguruan Pencak Silat (PPS) Tadjimalela, Perguruan Pencak Silat (PPS) Nasional Perisai Diri, dan Ikatan Keluarga Silat Putera Indonesia (IKSPI) Kera Sakti.

6. Prestasi Perguruan Pencak Silat

Hasil wawancara kepada pihak perguruan pencak silat dan anggota perguruan pencak silat tersebut, semua perguruan pencak silat di kabupaten karawang memiliki prestasi, baik di tingkat kecamatan, kabupaten, provinsi bahkan ada pula yang memliki prestasi di tingkat nasional dan internasional.

7. Perkembangan Perguruan Pencak Silat

Hasil wawancara dengan pihak perguruan pencak silat dan anggota perguruan pencak silat tersebut, perkembangan setiap perguruan pencak silat di kabupaten karawang beragam, ada yang memiliki perkembangan dengan sangat pesat dan ada pula yang memiliki perkembangan yang tergolong lambat dikarenakan keterbatasan sarana dan prasarana di dalam perguruan pencak silat tersebut.

8. Jadwal Latihan Perguruan Pencak Silat

Hasil wawancara dengan pihak perguruan pencak silat dan anggota perguruan pencak silat tersebut, mereka memiliki jadwal latihan masing - masing dimana rata - rata setiap minggunya jadwal latihan dilakukan sebanyak dua sampai empat kali. Namun ada perbedaan jadwal latihan saat persiapan untuk event pencak silat, yang tadinya hanya dua sampai empat kali dalam seminggu menjadi lima sampai sepuluh kali dalam seminggu dalam jadwal latihan di perguruan pencak silat tersebut.

\section{PENUTUP}

Berdasarkan hasil penelitian melalui observasi, wawancara, dan dokumentasi yang telah di jabarkan dan di jelaskan dalam pembahasan yang dilakukan dapat ditarik kesimpulan bahwa minat masyarakat terhadap pencak silat di Kabupaten Karawang, dikatakan cukup banyak untuk peminat dalam pencak silat di Kabupaten Karawang. Hal ini dapat dilihat dari segi jumlah penduduk Kabupaten Karawang dengan jumlah masyarakat yang minat dengan pencak silat dari setiap perguruan - perguruan pencak silat yang ada di Kabupaten Karawang. Dalam pelaksanaan latihan terdapat tiga unsur yaitu silaturahmi, olahraga dan spiritual. Dalam tiga kompetensi tersebut pelatih dan pengurus perguruan pencak silat sudah sepenuhnya melaksanakan tiga unsur tersebut dengan baik.

Apabila dilihat dari segi sarana dan prasarana, perguruan - perguruan pencak silat di Kabupaten karawang sudah termasuk cukup lengkap, tapi masih ada beberapa peralatan pendukung latihan yang kurang lengkap bahkan tidak ada. Hal ini menjadi tantangan bagi pengurus perguruan - perguruan pencak silat karena harus memodifikasi sarana dan prasarana yang tidak dimiliki oleh setiap perguruan pencak silat di Kabupaten karawang.

\section{REFERENSI}

Agung Nugroho, (2007). KETERAMPILAN DASAR PENCAK SILAT. FIK UNY

Arikunto, (2014). Prosedur Penelitian: Suatu Pendekatan Penelitian. Rineka Cipta

Dahlan, (2011). PENCAK SILAT Tinjauan Sejarah Budaya. Patanjala : Jurnal Penelitian Sejarah dan Budaya

Dinas Pariwisata dan Budaya, SEJARAH SINGKAT TERBENTUKNYA KABUPATEN KARAWANG (Sumber : Catatan Sejarah Karawang dari Masa ke Masa; T. Bintang)

Erwin Setyo. (2015). Sejarah dan Perkembangan Pencak Silat. Journal of Materials Processing Technology

Iswanto \& Rizanul Wahyudi, (2018). TINGKAT PEMAHAMAN ATLET TERHADAP PERATURAN PERTANDINGAN PENCAK SILAT KATEGORI TANDING HASIL MUNAS IPSI TAHUN 2012. Jurnal Prestasi Olahraga

Dipublikasikan Oleh :

UPT Publikasi dan Pengelolaan Jurnal

Universitas Islam Kalimantan Muhammad Arsyad Al-Banjari Banjarmasin 
Lubis, Johansyah. (2018). Model Latihan Teknik Dasar Serangan Tungkai. Jurnal Pendidikan Jasmani Dan Adaptif

Pendidikan Sejarah, (2018). PERKEMBANGAN IKATAN PENCAK SILAT INDONESIA (IPSI) TAHUN 1948-1973. Journal Pendidikan Sejarah

Erwin Setyo, (2015). Sejarah dan Perkembangan Pencak Silat Teknik-Teknik dalam pencak Silat Pengetahuan Dasar Pertandingan Pencak SIlat. Journal of Materials Processing Technology

Sugiyono. (2014). Metode Penelitian Kuantitatif, Kualitatif Dan R\&D. Bandung: ALFABETA

Yulio Pratama \& Trilaksana, (2018). Perkembangan Ikatan Pencak Silat Indonesia (Ipsi) Tahun 1948-1973. Avatara 